sucht wurde, besonders „heiße“ Themen und Thesen herauszuarbeiten, war eine gute Grundlage geschaffen für die Diskussion, ob die Tagung eine Erklärung zur deutschen Nachhaltigkeitsstrategie verabschieden solle.

Was folgte, war eine überaus engagierte und bisweilen hitzige Diskussion. Neben kritischen Stimmen überwog aber die Meinung, dass die Tagung ein Signal setzen solle und eine „Heidelberger Erklärung“ sinnvoll sei. Eine Diskussion und Abstimmung im Plenum wurde aber nicht für zielführend gehalten. So wurde eine Redaktionsgruppe beauftragt, die Diskussionen in den Arbeitsgruppen in die Formulierung der Erklärung zu integrieren. Im Anschluss an die Tagung wurde der Abschlusstext an alle Teilnehmenden versandt und von den meisten auch unterzeichnet. Der Text der Erklärung ist im „Spezial-Heft" der Zeitschrift „Ökologisches Wirtschaften“ abgedruckt. Dieses Heft dokumentiert auch alle Plenarbeiträge dieser Tagung.

Wie gesagt: Die Verabschiedung einer solchen Erklärung ist für eine wissenschaftliche Tagung gewiss nichts Gewöhnliches, sondern vielleicht eher ein Beispiel für eine sich entwikkelnde „post-normale Wissenschaft". Welche Rollenverteilung zwischen Wissenschaft, Politik und Zivilgesellschaft zukunftsfähig sein kann, ist nicht nur für Nachhaltigkeitsstrategien eine wichtige Frage. Ganz sicher jedenfalls war diese Konferenz ein Beitrag zu langfristigem Denken, das zumindest versucht, Ökologie, Soziales und Wirtschaft zusammenzudenken. In von Kurzfristigkeit und Ökonomisierung geprägten Zeiten ist das nicht wenig.

।)

\section{International Workshop \\ Mitigation and Adaptation in Climate Change: Toward a Mutual Agenda}

Essen, Germany, May 15 - 16, 2003

\section{by Nico Stehr, ITAS}

BONN, 3. Juni (dpa). Die Industrieländer werden künftig mehr klimaschädliche Treibhausgase ausstoßen. Die Emission vor allem an Kohlendioxyd könnte zwischen 2000 und 2010 in Europa, Japan, den Vereinigten Staaten und anderen Industrieländern um 17 Prozent steigen. Zu diesem Ergebnis kommt ein UN-Report, der am Dienstag in Bonn vorgestellt wurde. Damit würden die Ziele des Klimaschutzes verfehlt. Nach dem Kyoto-Protokoll müssen die Industrieländer ihre Treibhausgase von 1990 bis 2012 um 5,2 Prozent vermindern.

(Frankfurter Allgemeine Zeitung, 04.06.2003, Nr. 128/Seite 11)

The facts and the ideas that gave rise to the Essen workshop on "Mitigation and Adaptation in Climate Change: Toward a Mutual Agenda", held in May 2003 in the Kulturwissenschaftliche Institut in Essen - sponsored and organized by the Institute for Technology Assessment and Systems Analysis (ITAS) of the Forschungszentrum Karlsruhe and the Institute for Coastal Research of the GKSS, Geesthacht - were based on the supposition (1) that climate change is not so much an environmental set of issues that have a social component but is a societal, economic and cultural problem that has an environmental constituent, (2) that the discussions of mitigation of climate change and, more recently, adaptation to climate change share a common premise and (3) the fact that efforts to reduce the global emissions of greenhouse gases have not been very successful as the news item from a recent issue of the Frankfurter Allgemeine Zeitung demonstrates.

However, the approaches to mitigation and adaptation differ rather fundamentally on what action and what policies are necessary, possible and effective in response to the shared view that anthropogenic climate change which will have an as yet uncertain but varying impact on societies around the globe - is underway. Even if "addressed," the changes in global climate conditions generated by past, current and future greenhouse emissions will take decades if not more to "control".

Moreover, demographic, societal, economic and political developments, some of which we may be able to anticipate, will increase the vulnerability and the cost to societies of climate change, especially of extreme weather events whether or not such events become more frequent or more intense as the result of global climatic change. The political economy of nations will change, and as a result, the damages and the victims that may be observed will increase. As we become wealth 
ier, it will be more expensive to repair damages. Yet, doing nothing is not an option. It follows that adaptation is indispensable. ${ }^{1}$

The question of course then becomes how will adaptation be possible, on the basis of what knowledge, with the aid of what kinds of innovations (technological, symbolic), ${ }^{2}$ within what institutional arrangements (markets, regulation), generating what conflicts within and across societies, and how far and how fast can "climate-proofing" proceed?

A political focus and a research program on adaptation to climate change requires a change in perspective. It generally requires a de-naturalized view of the impact of climate on society and therefore of how society as well as the scientific community, in particular, the climate science research should respond to changing climatic conditions. At present in climate research and its derivative policies, most of the resources and action is reserved for mitigation purposes and impact studies. Knowledge on how societies coped and cope with climate change is quite limited. ${ }^{3}$

Moreover, there is not only "a grave mismatch between the knowledge that is needed to act locally and what is currently being done globally to generate knowledge about climate change, its impacts, and responses ..." (Wilbanks, Kates 1999, p. 616) but there is serious deficit of knowledge about adaptation processes and strategies to changing environmental conditions in modern societies. There also is a serious mismatch between resources devoted to standard models and scenarios that deal with climate impacts, the limited utility of such scenarios for adaptation measures and the resources allocated to the development of knowledge about adaptation that is not merely derivative of standard scenarios and models.

The workshop on adaptation and mitigation has made a first concerted effort to reduce some of the deficits that exist in scholarly reflections on adaptation issues and advance our understanding of a future adaptation research agenda.

The contributions to the workshop included the following:

- "Integrating Mitigation and Adaptation in Responding to Climate Change"

(Thomas J. Wilbanks, Oak Ridge National Laboratory, Oak Ridge, Tennessee, USA)
- "Human Adaptation to Climate Change: A Review of Historical Cases and Some General Perspectives"

(Ben Orlove, University of California, Davis, California, USA)

- "Mitigation and Adaptation: The Case for Continued Separation"

(Ian Burton, Toronto, Ontario, Canada)

- "Trade-Offs between Adaptation and Mitigation"

(Richard Tol, Universität Hamburg, Germany)

- "Enhancing Climate Response Options for Sustainable Development"

(Emma L. Tompkins and W. Neil Adger, Tyndall Centre for Climate Change Research, University of East Anglia, Norwich, and University of Southampton)

- "Misdefining Climate Change: Consequences for Science and Action"

(Roger A. Pielke jr., University of Colorado, Boulder, Colorado, USA)

- "Integrating Mitigation and Adaptation in Sectoral and Development Policies: Three Research Questions"

(Richard J.T. Klein, Potsdam Institut für Klimafolgenforschung, Potsdam, Germany)

- "Competitive Synergy between Responses to Climate Change"

(Chris West, Director, UK Climate Impacts Programme, Oxford, UK).

The workshop agreed on the basic premise that no matter what is done with regard to mitigation over the course of the next decades we need to adapt proactively to climate change. The specific results of the workshop may be summarized as a set of responses to the question of "What is to be done?" I will list some of the most significant challenges that face climate research that were identified in the course of the Essen workshop:

1. Identify the complementarities between adaptation (often at more local spatial institutional scales and shorter time scales) and mitigation - rather than assuming that they are opposed or simply overlapping.

2. The net effect of investing in synergies (in terms of reducing damages) is likely to be smaller than when half the money is invested in mitigation and the other half in adaptation. 
3. There is no single optimal mix of mitigation and adaptation, as this depends on local conditions, uncertainty and different preferences and values in society.

4. The actual implementation of mitigation and adaptation options is best done by sectoral planning and management agencies (e.g., energy and water companies, agricultural planners, coastal management agencies) as well as individuals. The capacity to respond (mitigative and adaptive capacity) is a crucial factor determining the success of any mitigation or adaptation measure.

5. We need to think more carefully about the appropriate scale for decisions about adaptation and mitigation. Can both be managed at the international scale and should they? The ability to tackle these issues at the right scale will only be discovered through trial and error. We need to make decisions, test them, evaluate them and then change them or proceed as necessary.

6. There may be a problem in presenting adaptation as legitimate. It should not compete against mitigation. One way of solving this problem could be to point out that the climate system has a long delay (inertia) because of the long life time of $\mathrm{CO}_{2}$.

A publication of the revised papers as a special issue of an international journal is planned and a follow-up workshop will be held in Essen in May of 2004.

\section{Notes}

1) After being almost absent from the discussion, an emerging focus of adaptation issues within the global climate science community and international negotiations may be noted throughout 2001: The 2001 IPPC report attends to adaptation issues and the Marrakech Accords to the UN Framework Convention on Climate Change established financial opportunities for setting up and implementing adaptation programs and activities: (1) The Least Developed Country Fund, (2) The Special Climate Change Fund and (3) the Kyoto Protocol Adoption Fund. With the exception of the third fund, contribution to these funds are voluntary. At the second COP 6 meeting in Bonn, the EU along with some other countries offered additional funds for these programs.

2) As Ausubel (2001, p. 33) for example suggests, "technology can make adapting to climate change, offsetting emissions, and preventing emissions cheap and effective."

3) The body of literature that might be consulted is mainly in the disciplines of history and archaeology (e.g. McIntosh, Tainter and McIntosh 2000). The emerging research agenda on adaptation to climate change will draw on the risk literature, studies that have dealt with natural hazards and disasters, hunger, famine, political ecology, governance, social inequality, development, theories of modern society, management, risk analysis, law, political economy and so on.

\section{Bibliography}

Ausubel, J.H., 2001: Some ways to lessen worries about climate change. In: Electricity Journal 14, pp. 24-33

McIntosh, R.J.; Tainter, J.A.; Keech McIntosh, S., 2000: Climate, history, and human action. In: McIntosh, R.J.; Tainter, J.A.; Keech McIntosh, S. (eds.): The Way the Wind Blows. Climate, History and Human Action. New York: Columbia University Press, pp. 1-42

Wilbanks, T.J.; Kates, R.W., 1999: Global change in local places: how scale matters. In: Climatic Change 43 , pp. $601-628$ 